\title{
METHODOLOGIES FOR \\ COMPILING NATIONAL INVENTORIES OF CONTAMINATED SITES AND CONDUCTING PRELIMINARY SITE SCREENING
}

\author{
PITSAKI K. ${ }^{1}$ \\ BOURA F.', 2 \\ PANTAZIDOU M. ${ }^{1, *}$ \\ KATSIRI A. ${ }^{3}$
}

\author{
${ }^{7}$ National Technical University of Athens \\ School of Civil Engineering, Div. of Geotechnical Engineering \\ 9, Iroon Polytechniou str., 157 80, Zografou, Greece \\ ${ }^{2}$ Ministry of Environment, Energy and Climate Change \\ Division of Environmental Planning \\ Water Management Section \\ 147 Patission str., 11251 Athens, Greece \\ ${ }^{3}$ National Technical University of Athens \\ School of Civil Engineering \\ Div. of Water Resources and Environmental Engineering \\ 5, Iroon Polytechniou str., 157 80, Zografou, Greece
}

Received: 29/06/12

Accepted: 01/07/13 *to whom all correspondence should be addressed: e-mail: mpanta@central.ntua.gr

\begin{abstract}
Procedures for compiling a national inventory of contaminated sites must take into account the technical state-of-the-art in the area of subsurface contamination and restoration, the national and supranational regulatory environment, as well as the national administrative infrastructure. Within this framework, this paper proposes a methodology of building a national inventory of potentially contaminated sites, which is based on activities of environmental relevance to the subsurface, i.e. soil and groundwater. As a next step, a screening system was developed, capable of estimating pollution potential of each site, for variable amount of available site-specific data. Depending on the nature of site data (actual or estimated) and the screening outcome, a site can be (i) delisted, (ii) assigned to an inactive list of potentially contaminated sites (iii) recommended for further desktop study and site visit or, (iv) recommended for both further study and in situ sampling. The advantage of the proposed approach is the identification of potentially contaminated sites on the basis of financial records linking activities with enterprises, which are more readily accessible compared with environmental records. The feasibility of transitioning from activities to sites has been demonstrated elsewhere. The present paper describes how data gaps are addressed by the site screening methodology with the aid of an application to a randomly selected real site in Greece.
\end{abstract}

KEYWORDS: Contaminated land, Subsurface polluting activities, Contaminated site inventories, Site ranking systems.

\section{INTRODUCTION}

\subsection{International experience}

The United States and Norway started addressing legislatively the problem of contaminated sites thirty years ago, while many European countries adopted specific regulations in the following years (de Sousa, 2001; Rodrigues et al., 2009a). The accumulated international experience is a valuable guide for countries without policies on contaminated sites, which, however, need to adopt selected best practices and blend them with their own administrative structure (Tarazona et al., 2005; Bezama et al., 2008; Rodrigues et al., 2009b). Member states of the European Union (EU) in particular must comply with existing EU legislation and, to the degree possible, accommodate legislation under preparation. Several EU directives address aspects of the contaminated sites 
problem. Among the most relevant for the work described herein are the directives for wastes (2008/98/EC), environmental impact assessment (2011/92/EC), integrated pollution prevention and control (codified version, 2008/1/EC, and recast directive, 2010/75/EU) and environmental liability $(2004 / 35 / E C)$, which requires remediation of land damage. The directive for soil protection, for years under preparation (COM(2006)232 final), deals specifically with contaminated sites and the obligation of each member state to compile a national site inventory.

Articles discussing national legislation on contaminated land do not provide details on the methodology of compiling inventories of contaminated sites. Long lists of activities may be mentioned but without explaining the rationale of selecting the specific activities (e.g. Royal Decree 9/2005; Tarazona et al., 2005). Alternatively, the starting point may be a list of few very general activities (e.g. industrial activities), based on which information is gathered by involving several different authorities that have to judge which facilities fall under the general description of each activity (Bezama et al., 2008). The two main ways of gathering information on potentially contaminated sites can be distinguished as follows. The first method is systematic and can be described as "top down". The categories of a list of polluting activities are defined first and then the list is populated by linking activities with sites, following procedures suiting the administrative structure and the record keeping infrastructure of a country. This is the method proposed by the authors, described in detail elsewhere (Pantazidou et al., 2011) and summarized herein in Section 2. The alternative approach can be described as "bottom up". Existing records are merged and mined for information on specific sites, which can then be grouped in categories. The two methods of identifying sites can be used in a complementary manner. In some countries, information is supplemented by reports submitted by citizens for sites warranting investigation (e.g. USEPA, 2002).

Characterization of potentially contaminated sites has widely adopted a risk-based approach, throughout the United States and many EU countries. This approach either uses the pollutant linkage paradigm (source-pathway-receptor), or concentration thresholds of substances in soils, or combines both decision tools, frequently taking into account current or planned land uses (Bardos et al., 2002; Rodrigues et al., 2009a). Site-specific risk assessment is conducted in a tiered manner, the starting point being a preliminary survey prior to intrusive assessments, in order to evaluate pollutant linkages and recommend high priority sites for further investigation. This site-specific initial screening is based on available data for the site, without reliance on contaminant concentration measurements. The US preliminary assessment (PA) methodology (USEPA, 1991), which served as a basis for the methodology proposed herein, scores each exposure pathway considering riskrelated factors, i.e. waste characteristics, likelihood of release and human and environmental targets. The aggregated score of all pathways results in an overall site score, which is the principal, though not the only one, criterion for inclusion to the list of sites that warrant further investigation. This rigid computational approach allows for reproducible results, i.e. given the same sites and site data, the PA is expected to reach similar conclusions regardless of the individual assessor, but has been criticized for being sensitive to data availability (Bergius and Oberg, 2007). In addition, also according to Bergius and Oberg (2007), the PA methodology places an unreasonably high weight to the surface water pathway. The development of an alternative, simplified screening system is described herein in Section 3, while an example application is given in Section 4.

\subsection{The goal of the paper}

The goal of this paper was to present a complete framework including a methodology for compiling national inventories of contaminated sites of general applicability and specifically suitable for Greece, complemented by a preliminary site screening methodology. With this aim in mind, the methodology developed is to a large extent based on EU regulations, and hence can be applicable in different countries, with appropriate modifications of choices made specifically for Greece, which are highlighted. The methodology for compiling inventories lends itself to successive pruning based on activity-specific data and, at a second step, site-specific data. Moreover, the methodology for site screening is able to address data gaps typically anticipated during desktop studies.

\section{METHODOLOGY FOR COMPILING INVENTORIES}

\subsection{Developing a list of potentially contaminating activities}

As mentioned, the methodology for compiling inventories of contaminated sites has been presented in more detail elsewhere (Pantazidou et al., 2011); only the major features of the compilation procedure will be summarized herein. The core of the methodology consists of two decisions of 
broad relevance. The first decision was to build an inventory compatible with current and anticipated European regulations. Entities familiar to regulators from legislative instruments of wide applicability are included in order to make the inventory user-friendly. The second decision was to adopt a "top down" approach. The starting point is a list of activities with potential to pollute soil and groundwater, which is used to create a list of potentially contaminated sites, producing thus a comprehensive site inventory.

These broad decisions were supplemented with specific desiderata for the structure and content of the inventory. It is desirable that the list of activities is structured in order to provide easy access. A similar structure will be transposed to the site inventory, facilitating thus the development of a database that will be easily searched and maintained. For this purpose, a tree-like hierarchical list of activities was developed, consisting of five levels: 1) major sectors, 2) sectors, 3) subsectors, 4) categories and 5) subcategories. The list is compatible to the Statistical Classification of Economic Activities within the EU (EUROSTAT, 2008), commonly referred to as the NACE (Nomenclature statistique des activités économiques dans la Communauté européenne) codes, up to a four-digit level of analysis. Compatibility with the NACE coding system allows linking of activities with enterprises and, ultimately, sites, through the records of national statistical authorities. The types of activities included were selected from key EU and Greek documents, which deal with soil protection, pollution prevention and environmental impact assessment (EIA). The approach followed to synthesize activity groups is described next.

The topmost level of the taxonomy of activities potentially polluting soil and groundwater consists of seven major sectors, $A$ to $G$, as shown in Table 1. The major inspiration for selecting these seven major sectors as a starting point was the list of polluting sources (Box 5) in JRC (2011). Subsequent breakdown of activities in sectors and subsectors was based on the grouping of activities in 2008/1/EC (Annex I), 2011/92/EC (Annexes I \& II) and 4014/2011/GR (Ministerial Decisions 1958/13-1-2012/GR and 20741/8-5-2012/GR, Groups III-V, VII, IX, XI, XII). For major sectors A (waste management), B (industrial activities) and, partly, C (commercial activities - C4: printing facilities) breakdown of activities follows primarily the structure (although not always the order) of 2008/1/EC, in combination with the list of the NACE codes. At a finer level, activities are supplemented with those included in 2011/92/EC and 4014/2011/GR. Major sector E appears only in JRC (2011) and in the proposed directive for soil protection (COM(2006)232 final). For the remaining major sectors, the breakdown of activities resulted from a synthesis of the NACE codes, 2011/92/EC and 4014/2011/GR.

Table 1. Example of the tree-like structure of the activity list: top level of potentially polluting activities (major sectors $A$ through $\mathrm{G}$ ) and breakdown of major sector $\mathrm{B}$

\begin{tabular}{ll|l}
\hline \multicolumn{2}{c|}{ Major sectors A - G } & \multicolumn{1}{c}{ Sectors B1-B7 } \\
A & Waste management (A1 - A18) & B1 Energy production and distribution \\
B & Industrial activities (B1 - B7) & B2 Oil industries \\
C & Commercial activities (C1 - C5) & B3 Chemical industries \\
D & Extractive activities (D1 - D5) & B4 Metal working industries \\
E & Military installations (E1, E2) & B5 Production of electrical and electronic equipment \\
F & Storage facilities (F1 - F3) & B6 Glass, ceramics and building materials industries \\
G & Transport-related activities (G1 - G5) & B7 Other industrial activities \\
\hline
\end{tabular}

Development of the tree-like list resulted in a total number of 302 activities, those that correspond to the tips of the branches of the tree. About $2 / 3$ of those belong in major sector $B$ (industrial activities) and $1 / 10$ in major sector $A$ (waste management). The list is presented in a table format that indicates the correspondence of each activity to the key documents previously mentioned, reflecting thus the method of its development and facilitating links with key legislative documents. The list also gives the correspondence between activities and types of waste, codified according to the European Waste List (EWL) coding scheme (2000/532/EC). Clearly, knowledge of waste types can provide partial only indication of the severity of potential pollution, without the complementary information on raw materials associated with each activity. 


\subsection{Testing the developed list of potentially contaminating activities}

Because there is no unique way of compiling a list of polluting activities, the list must be subjected to tests in order to evaluate its soundness and make any required modifications. Two different types of tests were used for this purpose. In one type of test, the contents of the list are checked against contents of similar lists, provided that differences in aggregation are accounted for. One such list, which comprises the 40 activities of most relevance to soil and groundwater contamination, is published by the European Environment Agency (EEA, 2002) and reproduced by the workgroup of the European Commission in their report on soil contamination from local sources (Van-Camp et al., 2004). The two lists can be compared at the sector - subsector levels with good agreement. The other type of test includes usability trials, which aim to demonstrate that the transition from a list of activities to an inventory of sites can be accomplished in a systematic manner. For this purpose, two pilot applications were designed and executed, as described in detail elsewhere (Pitsaki, 2010; Pantazidou et al., 2011).

Once a comprehensive list of potentially polluting activities is available, the transition from activities to potentially contaminated sites can be accomplished in a few alternative ways. Authorities holding environmental records can contribute entries from their records. This is perhaps the less complicated but also the less systematic way, the success of which depends on the quality of record keeping on behalf of the authorities. Its result will most probably resemble that of a "bottom up" approach to site inventorying. On the contrary, the methodology proposed herein capitalizes on the widely used NACE codification of activities that allows systematic identification of sites, independently of the availability and the accessibility of environmental records. Searches based on NACE codes can be made either through national agencies for statistical data gathering or through professional chambers. In Greece, such sources include the Hellenic Statistical Authority (EL.STAT. www.statistics.gr) and, for Athens in particular, the Athens Chamber for Commerce \& Industry (ACCI - www.acci.gr).

Given the anticipated potential gaps in statistical data for Greece, the usability trial test for the developed list was designed as a verification test. Records for all installations corresponding to two activity types were first obtained from ACCl. One installation was selected at random from each record. Then, data on the same two activity types were obtained from EL.STAT. The verification test would be judged successful if the randomly selected installation from the ACCI records could also be identified, independently, from the EL.STAT. records. The two pilot applications, which were designed and executed as verification tests, were successful, thus providing support to the feasibility of transitioning from polluting activities to potentially contaminated sites (Pantazidou et al., 2011).

\section{METHODOLOGY FOR SITE SCREENING}

\subsection{Rationale of the methodology to estimate pollution potential and impact}

The rationale of the proposed methodology rests on two major decisions. The first emphasizes soil and groundwater protection, i.e. the least regulated environmental media, particularly in Greece. To this end, unlike the US methodology, no explicit distinction is made among air/surfacewater/groundwater/soil media. Instead, potential contamination of groundwater resources, especially for drinking purposes, is considered to be the principal threat. Accordingly, contaminant fluxes to surface water or air are indirectly accounted for in the site screening process. The second major decision of the methodology is of regulatory nature. The aim is to structure a screening system capable of estimating pollution potential by making use of existing site-specific information, while at the same time ensuring that the system will still produce a conservative outcome even in the absence of some types of site-specific data. The site-specific information is mainly sought in the EIA reports (submitted according to 15393/2332/2002/GR until 2011 and 4014/2011/GR thereafter), which are complemented with independent desktop surveys. The EIA reports must cover a range of impacts, hence, it is anticipated that some may include only limited information for the purpose of site screening. In view of anticipated data gaps it is important (1) to select a set of screening criteria that can be directly or indirectly assessed based on limited available evidence and (2) to use conservative assumptions to overcome uncertainties and address data gaps. The approach of worst case scenarios, which has been widely embraced (e.g. USEPA, 1991; Tarazona et al., 2005), avoids underestimation of potential risks, but also time consuming inquiries to address data gaps, and hence speeds up the preliminary screening process. What is more, it offers site owners a strong incentive to improve the quality of reported data, while a further refinement of the hypothesized conditions could be performed on the basis of subsequently obtained information. Based on the 
above decisions, development of the site screening system will adhere to a set of key impact-related types of information ("indicators" hereafter) oriented to groundwater protection and robust to data gaps. In addition, it is desirable that the system be presented in a simple and practical layout to make it easily accessible to the parties interested in the assessment process.

\subsection{Selecting key indicators, respective parameters and score values}

The selection of the key indicators for the likely impact of potential contamination was made within a framework that considers the nature, likelihood and extent of contaminant releases, their migration potential in groundwater and their effects on receptors, giving priority to human health. A total of 15 key indicators was selected and then represented, where possible, with parameters similar to those used for the preliminary assessment (PA) according to the US methodology (USEPA, 1991). The principal aim of this process was to ensure a good level of agreement between the two methodologies in particular with respect to groundwater pathway considerations, bearing in mind the decision to structure a system robust to data gaps, and hence, less sophisticated than the US approach. Each one of the independently selected indicators and the degree to which they agree with the PA methodology of USEPA (1991) are described in more detail elsewhere (Pitsaki, 2010). For ease of communication, the 15 indicators are grouped in three categories, "contaminant", "facility" and "surrounding area". The level of detail desired for the screening system was deemed compatible with a maximum numerical range of 0 to 5 points for each indicator. The set of proposed key indicators and their representative parameters, the selected range of impact and assigned score values are presented in Table 2.

The "contaminant" group of the proposed indicators includes toxicological data on human health (No 1), mobility (No 2) and persistence (No 3), assessed by carcinogenicity evidence, retardation factor (a function of the soil-water partition coefficient) and half-life, respectively. Volatility (No 4) is also included, to address the air pathway, and assessed by vapor pressure. The aforementioned parameters correspond to a single, nominal contaminant of concern associated with the main activity taking place at the site. Linking site activities at a sector or subsector level to associated contaminant types meets the objective of a system robust to data gaps, and has been adopted by various national guidelines as a preliminary reference for hazard identification, e.g. Western Australia guidelines (GWA DE, 2004) and US Brownfields Road Map (BTSC, 2013). Bergius and Oberg (2007) also used only the contaminant that received the highest risk estimate for the risk classification of sites, in order to simplify the application of the Swedish preliminary assessment methodology in their study.

The indicators in the "facility" group assess in alternate ways the potential of the facility to pollute and the magnitude of the possible pollution, while the indicators in the third group assess the impact from a potential release from the facility to the surrounding area. Consistent with the decision to produce a conservative estimate, the indicators under the "facility" and "surrounding area" groups allow for some overlapping information. Examples include quantity of hazardous wastes/materials (No 5) and capacity of the facility (No 6), which is related to the overseeing authority (the higher the capacity, the more central the overseeing authority). Another example is level of source containment (8ii) and violations of environmental permits recorded by the Hellenic Environmental Inspectorate (HEI) (No 9), which possibly indicate subsurface pollution incidents. It is noted that the HEI may provide lists of the non complying facilities along with imposed fines from the competent authority, which is determined based on the amount of the imposed fine (MEECC, 2010). In addition, Table 2 includes four indicators that are assessed with two separate parameters, concerning the characteristics of the contaminant source (8i, 8ii), of the nearest well (12i, 12ii), of land use (14i, 14ii) and of the impact from other contaminated sites in the vicinity (15i, 15ii). Double parameters (i and ii) are used in order to achieve more transparent scoring for the assessment of indicators that are deemed unlikely to be reported in the EIA reports (No 8ii, No 12ii, No 14ii, No 15ii), and, hence, involve hypotheses on actual conditions and additional survey. Evaluation of source characteristics (No 8) is a prime example of this case. Engineering plans included in the EIA reports may depict the location of potential sources (No 8i), while data on any engineered structures containing the sources (roofs and platforms, double liners etc.) are unlikely to be known without onsite visit (No 8ii). In either case, in the absence of specific information (i.e. location of potential sources), the worse case will be assumed (underground disposal/storage: +3 ). In the presence of both source types (underground and surface) at the site, only the deepest point of potential release, i.e. underground sources, is assessed (i.e. score is again: +3 ). Clearly, the assessment of hypothesized conditions shall also 
follow the worst case scenario. However, for these hypothesized data, it is considered appropriate to assign maximum score values somewhat lower than those of parameters requiring data that are expected to be readily available. For this reason, the maximum score for the level of source containment is +2 (No 8ii), lower than the maximum of +3 assigned for the source location (No $8 \mathrm{i}$ ).

Table 2. Site screening indicators, representative parameters and assigned score ranges according to the proposed methodology

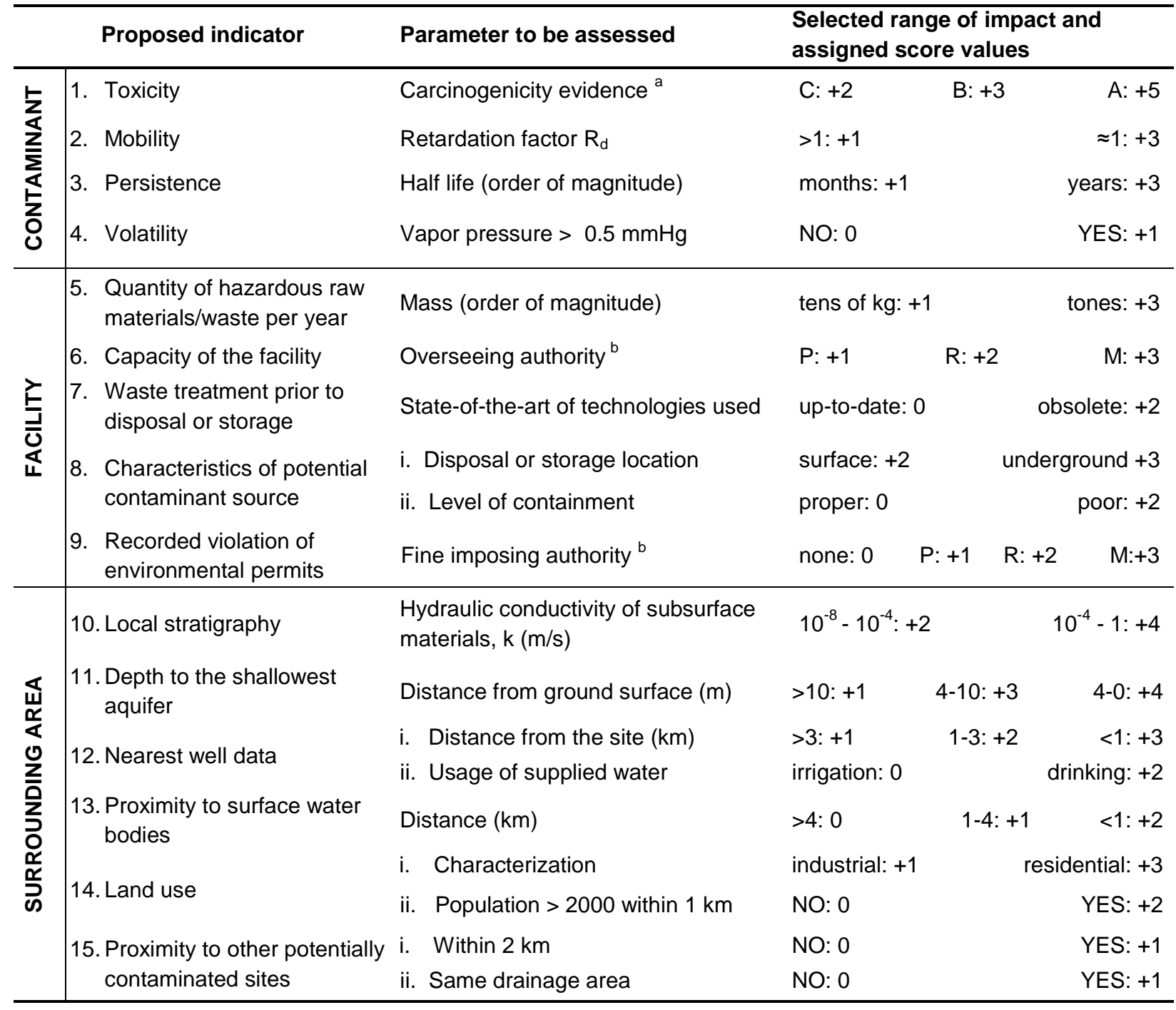

a C - 'suggestive evidence of carcinogenic potential', B - 'likely to be carcinogenic to humans', A - 'carcinogenic to humans' (USEPA, 2005); b P: Prefecture, R: Region, M: Ministry

Depending on their type, parameters are evaluated as numbers or descriptive characterizations varying from low to high impact. For the assignment of numerical score values, the indicators deemed most critical were assigned higher maximum score values (e.g. toxicity, No 1). Gradation of values was selected to be disproportionate in many cases (e.g. No 2, No 5, No 10, No 14i), in order to emphasize higher pollution impact. The separate assessment of parameters unlikely to be readily available is expected to reveal sites with highly unfavorable conditions. Characteristic examples of such parameters are poorly contained underground tanks (No 8ii) and drinking water wells within a $1 \mathrm{~km}$ radius from the site (No 12i).

A potentially contaminated site examined may thus accumulate a total score from 14 to 50 , with maximum scoring of 12,16 and 22 for the contaminant, facility and surrounding area categories, respectively. It can be observed that facility-related indicators are moderately weighted, hence decreasing the possibility of overestimating the contribution of the facility to the pollution potential of the site, despite the fact that many complementary indicators are included. Moreover, consideration 
of the proximity to other potentially contaminated sites (No 15) helps focusing on areas with high concentration of facilities. A refinement of assigned score values will be possible after the pilot application of the screening system, as described in Section 4, to a number of sites with a range of pollution potential. Based on the screening outcome, a site classification scheme can then be proposed, i.e. matching score ranges to pollution potential classes and recommendations for further investigation. One such scheme could be as follows: 10-20: site is removed from the list, 20-30: site is moved to an inactive list of potentially contaminated sites (such sites could be delisted only after obtaining complete site-specific information and a site visit), 30-40: potentially contaminated site that requires further desktop study and site visit, 40-50: the facility requires further study and sampling.

\section{A SITE SCREENING EXAMPLE}

The potentially contaminated site selected for the site screening example has been linked to activities in Sector B3: Chemical industries (see Table 1) and specifically Subsector B3.9: production of coatings (paint, varnishes, enamel, glues, inks) through mixing and packaging (4014/2011/GR, Group IX, No 98). The corresponding NACE08 code is 20.30 (EUROSTAT 2008) and the respective EWL codes are $0801-0803(2000 / 532 / E C)$. The EIA report for the site was located at the Attica region and was supplemented with additional sources of hydrogeological information for Attica.

The starting point for the application of the screening system developed in Section 3 is the selection of one contaminant, nominally representative of Subsector B3.9. This nominal contaminant overrides the information provided in the EIA report, in the absence of comprehensive logs of all raw materials used and waste produced at the site or site-specific chemical analysis data from soil and groundwater samples. The selection of the contaminant representing Subsector B3.9 was accomplished by consulting sources linking activities and contaminants, as well as by reviewing identified contaminants of concern in soil and groundwater at sites with similar industrial activities. The Western Australia guidelines (GWA DE, 2004) identify metals, solvents and resins as some of the potential contaminant types associated with paint manufacturing, blending or mixing. From these groups, the contaminant group of solvents was deemed of primary concern for the coatings industry. In order to identify one representative within this broad contaminant category, the US database of National Priorities List (NPL) sites was searched (USEPA, 2013a) for releases of hazardous substances associated with coatings production facilities. It is noted that USEPA considers contaminants of concern the substances that are addressed by cleanup actions at NPL sites and not the preliminary lists of potentially site-related contaminants. Six sites were selected from the NPL list for in-depth study, an overview of which is presented in Table 3. Four sites were facilities manufacturing paints or other coatings, including warehouses, tanks or drums for storage of raw materials (pigments, resins, solvents etc.) or of wastes (e.g. spent solvents, rinsate from washing out mixing tanks, paint cans) (USEPA, 1986; 1992; 1998; 2013b). Two sites with paint manufacturing waste disposal were also included in Table 3 (USEPA, 1989; 2013c), anticipating the possible presence of waste disposal areas at potentially contaminated sites under Subsector B3.9 (e.g. trenches open for an extended period of time to allow for volatilization of liquid wastes).

A variety of contaminants of concern has been identified in the solvent category at the reviewed sites. Based on human carcinogenicity information from the USEPA Integrated Risk Information System (IRIS), the list is further reduced to include only substances with higher weights of evidence for human carcinogenic potential (i.e. A and B in Table 2). Benzene, a known human carcinogen, was detected at five of the six sites, however, according to Fetter (1999) and BTSC (2013) it is not typically related to paint industry sites. Besides, benzene, being a component of petroleum products, could be related to various potentially contaminating activities, such as gas plants, petroleum refining and reuse plants, gasoline stations, and hence, its detection could also imply transport from off site sources. Trichloroethylene (TCE), used as a general solvent or as a component of solvent blends, is also characterized as carcinogenic to humans (USEPA IRIS, 2013). It is used in manufacturing of adhesives, lubricants, paints, varnishes and paint strippers, among numerous other uses (USATSDR, 1997). Trichloroethylene was identified as a contaminant of concern at three sites manufacturing paints (USEPA, 1986; 1992; 1998) and is also related to the paint industry according to Fetter (1999) and BTSC (2013). At one of these sites (USEPA, 1998) polychlorinated biphenyls (PCBs) were identified as the primary contaminant. Although PCBs are not extensively used in paint manufacturing operations (they are used mainly as dust suppressants) and sorb strongly to soils, their mobility to the subsurface may increase in the presence of chlorinated solvents such as TCE, which is considered the reason of their migration to groundwater (USEPA, 1998). Trichloroethylene 
may therefore indicate additional hazards and is selected as the nominal contaminant for Sector B3.9. Hence, according to Table 2, the default value for indicator No 1 is +5 at all sites linked with activity B3.9.

Table 3. Six National Priorities List sites associated with coatings production facilities and identified contaminants of concern (USEPA, 2013a)

\begin{tabular}{|c|c|c|}
\hline \multirow{2}{*}{$\begin{array}{l}\text { Site No / onsite } \\
\text { activity / NPL } \\
\text { status (Ref.) }\end{array}$} & \multicolumn{2}{|c|}{ Identified contaminants of concern } \\
\hline & Soil & Groundwater \\
\hline $\begin{array}{l}\text { paint formulation } \\
\text { through mixing of } \\
\text { pigments with resins } \\
\text { and solvents / final } \\
\text { (USEPA, 1992) }\end{array}$ & $\begin{array}{l}\text { TCE, Tetrachloroethene, Toluene, } \\
\text { Ethylbenzene, Xylenes, PAHs, PCBs, } \\
\text { Naphthalene, n- } \\
\text { Nitrosodiphenylamine, Antimony, } \\
\text { Arsenic, Barium, Beryllium, } \\
\text { Chromium, Cadmium, Copper, Lead, } \\
\text { Manganese, Mercury, Nickel, } \\
\text { Thallium, Vanadium, Zinc. }\end{array}$ & $\begin{array}{l}\text { Chloroform, Chloromethane, Cis-1,2- } \\
\text { dichloroethene, Dichloromethane, 1,1,2-TCA, } \\
\text { TCE, Tetrachloroethene, Acetone, Benzene, } \\
\text { Carbon disulfide, Toluene, Ethylbenzene, } \\
\text { Xylenes, Naphthalene, 2,4-Dimethylphenol, 2- } \\
\text { Methylphenol, 4-Methylphenol, Antimony, } \\
\text { Arsenic, Barium, Beryllium, Cadmium, } \\
\text { Chromium, Copper, Lead, Manganese, } \\
\text { Mercury, Nickel, Selenium, Silver, Vanadium, } \\
\text { Zinc. }\end{array}$ \\
\hline $\begin{array}{l}2 . \\
\text { manufacturing of } \\
\text { water-based latex } \\
\text { paints and organic- } \\
\text { based solvent paints / } \\
\text { final } \\
\text { (USEPA, 1998) }\end{array}$ & $\begin{array}{l}\text { PCBs; Benzo[a]anthracene, } \\
\text { Benzo[a]pyrene, } \\
\text { Benzo[a]fluoranthene, Indeno(1,2,3- } \\
\text { cd)Pyrene, Phenanthrene, Antimony, } \\
\text { Arsenic, Chromium, Chrysene, Lead, } \\
\text { Manganese, Mercury, Nickel, } \\
\text { Vanadium. }\end{array}$ & $\begin{array}{l}\text { 1,2-Dichloroethane, TCE, Benzene, } \\
\text { Benzo[a]anthracene, Benzo[a]pyrene, } \\
\text { Ethylbenzene, Toluene, Xylenes, 1,2,4-TCB, } \\
\text { PCBs, Naphthalene, Phenols (paint-related } \\
\text { polyurethane, polyamide paint resins), Arsenic, } \\
\text { Lead, Manganese. }\end{array}$ \\
\hline $\begin{array}{l}3 . \\
\text { production of pigments } \\
\text { and varnish varieties / } \\
\text { final } \\
\text { (USEPA, 2013b) }\end{array}$ & $\begin{array}{l}\text { Free-phase product (Benzene, } \\
\text { Ethylbenzene, Xylene, Naphthalene, } \\
\text { 2-Methylnaphthalene), Di-n-butyl } \\
\text { phthalate, Bis(2-ethylhexyl)phthalate, } \\
\text { Pentachlorophenol, Arsenic, Cyanide, } \\
\text { Chromium, Copper, Lead. }\end{array}$ & $\begin{array}{l}\text { Free-phase product (Benzene, Ethylbenzene, } \\
\text { Xylene, Naphthalene, 2-Methylnaphthalene) - } \\
\text { insufficient data. }\end{array}$ \\
\hline $\begin{array}{l}4 . \\
\text { manufacturing of paint, } \\
\text { varnish and resin } \\
\text { products / final } \\
\text { (USEPA, 1986) }\end{array}$ & $\begin{array}{l}\text { Chloroform, Chlorobenzene, } \\
\text { Dichloromethane, Toxaphene, PCBs, } \\
\text { Benzene, Ethylbenzene, Toluene, } \\
\text { Xylene, Benzo[a]anthracene, } \\
\text { Benzo[b]fluoranthene, Base neutral } \\
\text { acids, Naphthalene, Diphenylamine, } \\
\text { Cadmium, Chromium, Chrysene, } \\
\text { Mercury, Nickel, Zinc. }\end{array}$ & $\begin{array}{l}\text { 1,1-Dichloroethane, TCE, Dichloromethane, } \\
\text { Benzene, Ethylbenzene, Toluene, Xylenes, } \\
\text { Base neutral acids, Aroclor-1248, PCBs, } \\
\text { Naphthalene, 2-Methylnaphthalene, Di-n-butyl } \\
\text { phthalate, Arsenic, Barium, Chromium, Lead, } \\
\text { Nickel, Vanadium, Zinc. }\end{array}$ \\
\hline $\begin{array}{l}\text { 5. } \\
\text { disposal trenches of } \\
\text { liquid and solid paint } \\
\text { manufacturing wastes } \\
\text { / final } \\
\text { (USEPA, 1989) }\end{array}$ & $\begin{array}{l}\text { Chloroform, Dibutyl phthalate, Bis(2- } \\
\text { ethylhexyl) phthalate, Arsenic, } \\
\text { Cadmium, Chromium (III), Lead, } \\
\text { Mercury, Nickel, Zinc. }\end{array}$ & $\begin{array}{l}\text { 1,2-Dichloropropane; Benzene, Toluene, } \\
\text { Ethylbenzene, Xylenes, Methyl ethyl ketone, } \\
\text { Beryllium, Cadmium, Chromium (III), Lead. }\end{array}$ \\
\hline $\begin{array}{l}\text { 6. } \\
\text { paint waste disposal } \\
\text { area / proposed } \\
\text { (USEPA, 2013c) }\end{array}$ & PAHs, Arsenic, Chromium, Lead. & Insufficient data \\
\hline
\end{tabular}

TCE: trichloroethylene, PAHs: polyaromatic hydrocarbons, PCBs: polychlorinated biphenyls, TCA: trichroroethane, TCB: trichlorobenzene

Table 4 includes the values for all parameters for the example site and indicates whether information on these parameters was a) included in the EIA report, b) located through another source or c) hypothesized. Certain selected parameters will be commented upon further herein, in order to provide indicative examples of the decisions that have to be made during the application of the screening methodology and of their implications. In order to err on the side of caution, the quantity estimate of hazardous wastes handled at the site shall include even temporal onsite storage, prior to removal and offsite treatment from licensed companies (No 5: +3 ). According to the EIA report, the example site handled over a hundred of tones of hazardous wastes; this does not include hazardous 
raw materials which could not be quantified based on the EIA report data. Quantity data on this order of magnitude, anticipated at numerous sites, could perhaps indicate the need to extend the range and the gradation of impact for indicator No 5 , thus assigning a score of +5 to quantities of hundreds of tones, in order to avoid underestimation of actual quantities. However, this potential drawback of the screening system is balanced to an extent by the inclusion of the overlapping information on the capacity of the example facility which adds to the site score. In addition, as it was anticipated, the location of potential sources at the example site was reported in the EIA (underground tanks). However, because of the limited evidence on the level of source containment, as well as due to the presence of an absorbing septic tank, it was decided to assume the worst case scenario, i.e. poorly contained underground sources (No 8ii: +2 ).

Table 4. Screening results and origin of respective data for the coatings example site (see Section 3 and Table 2 for definition of indicators 1-15)

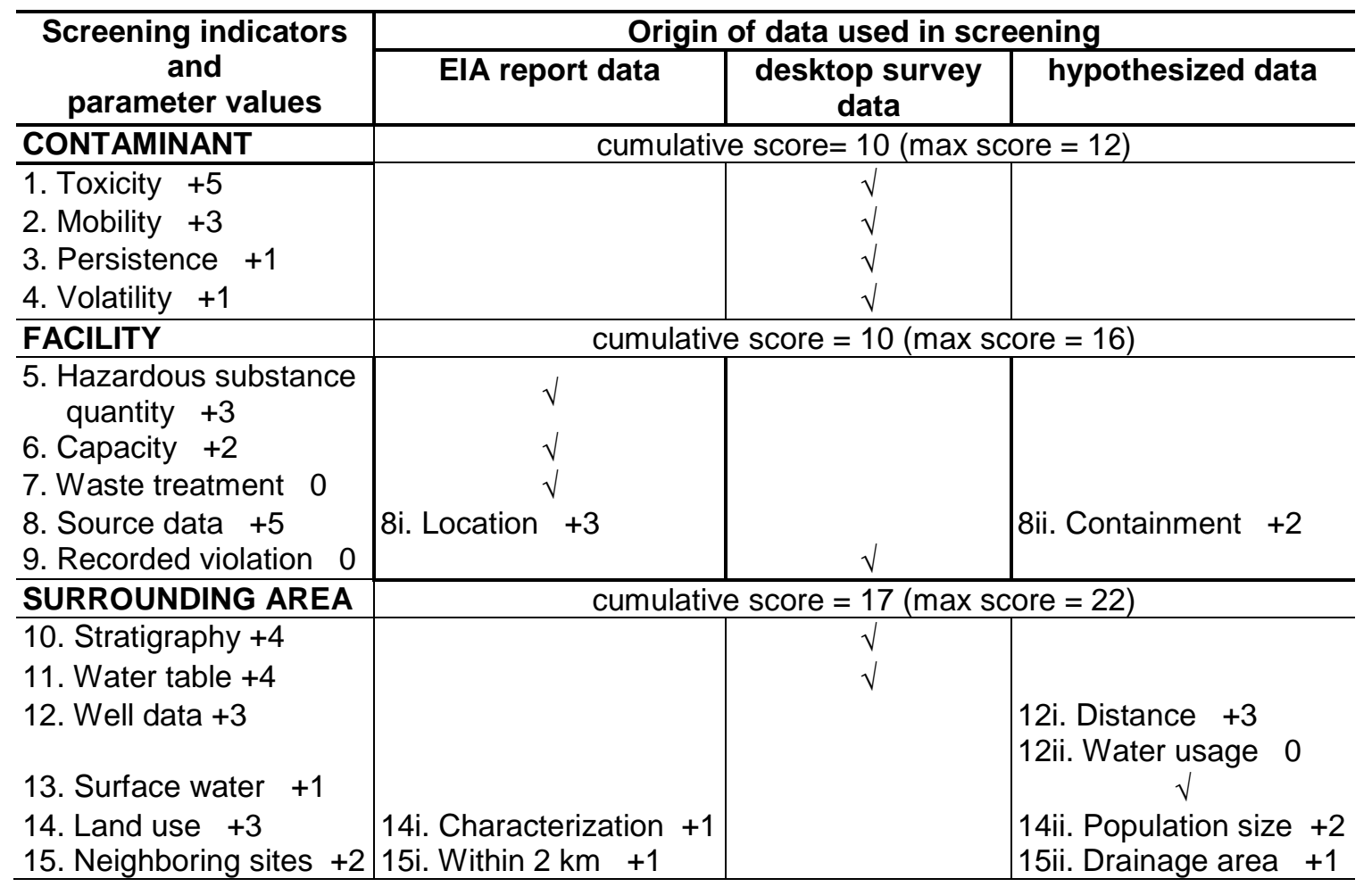

As indicated in Table 4, several parameters from the surrounding area group were assessed based on hypothesized data, i.e. were not included in the EIA report nor located through independent surveys. For instance, the EIA report states that the site belongs to a land use zone characterized as a purely industrial area, with facilities causing moderate disturbance to the environment. However, agricultural and livestock uses are also noted in the EIA report within a $1 \mathrm{~km}$ radius from the site and residences within a $2 \mathrm{~km}$ radius. In order to account for this discrepancy without being overly conservative, the following decisions were made. Following the designation of the EIA report, parameter 14i was assigned an industrial zone characterization, and a score of +1 . However, considering that the municipality where the example site belongs has a population of over 20,000 residents, the $1 \mathrm{~km}$ target distance for the exposed population (see Table 2) was not considered as a strict numerical boundary and a score of +2 was assigned to parameter $14 \mathrm{ii}$. In addition, the combined industrial and agricultural or livestock uses suggest a large number of wells in the study area. Data on their number, however, should be sought at the Department of water resources of Attica region. Similarly to indicator No 14, a balanced decision was made for No 12: whereas the distance from the nearest well was conservatively assumed to be the minimum (No 12i: +3 ), it was also assumed that existing wells serve only irrigation or industrial purposes (No 12ii: 0). It is noted that in the case that the distance from the nearest well is greater $(1-3 \mathrm{~km})$, the overestimation of this parameter adds +1 to the site score (see Table 2).

As shown in Table 4, the example site accumulated a score of +37 . However, as it becomes evident from the discussion for indicators 8,12 and 14, a refinement of hypothesized data could reduce the 
site score to as low as +32 . The transparent scoring of hypothesized conditions with double parameters is expected to facilitate such refinements. What is more, the conservatism of the proposed methodology is expected to serve as a motive for enterprises to procure comprehensive EIA reports.

\section{CONCLUDING REMARKS}

This paper described the development of a structured list of activities with potential to pollute soil and groundwater that is compatible with EU legislation and adaptable to national regulatory environments and of a screening system capable of estimating pollution potential of each site for a variable amount of data. The screening methodology adopts a conservative approach, which avoids time-consuming inquiries to address data gaps and provides incentives to site owners for comprehensive environmental reporting. An application of the screening methodology to a randomly selected real site provided examples of data gaps to be anticipated in typical EIA reports. In addition, the application demonstrated the type of decisions that need to be made in the absence of sitespecific data, as well as the impact of information missing from EIA reports. Depending on the nature of site data (actual or estimated) and the screening outcome, a site can be (i) delisted, (ii) assigned to an inactive list of potentially contaminated sites (iii) recommended for further desktop study and site visit or, (iv) recommended for both further study and in situ sampling.

\section{REFERENCES}

1. Bardos P., Lewis A., Nortcliff S., Matiotti C., Marot F. and Sullivan T. (2002), Review of Decision Support Tools for Contaminated Land and their Use in Europe - A report from the Contaminated Land Rehabilitation Network for Environmental Technologies (CLARINET), Austrian Federal Environment Agency.

2. Bergius K. and Oberg T. (2007), Initial Screening of Contaminated Land: A Comparison of US and Swedish Methods, J. of Environmental Management, 39, 226-234.

3. Bezama A., Agüero R., Márquez F., Barrera S., Salazar N. and Lorber K.E. (2008), Land register of contaminated sites in an industrial Chilean region: Identification and evaluation of suspected sites, Waste Management, 28(3), 588-596.

4. BTSC (The Brownfields and Land Revitalization Technology Support Center) (2013), Contaminant Groups by Site Type (online guide). Available from http://www.brownfieldstsc.org/roadmap/contBySiteType.cfm. (Accessed July 10, 2013).

5. $\operatorname{COM(2006)232~final,~Proposal~for~a~Directive~of~the~European~Parliament~and~of~the~Council~}$ establishing a framework for the protection of soil and amending Directive 2004/35/EC.

6. de Sousa C. (2001), Contaminated sites: The Canadian situation in an international context, J. of Environmental Management, 62(2), 131-154.

7. EC (2000) 2000/532/EC, Commission Decision of 3 May 2000 replacing Decision 94/3/EC establishing a list of wastes pursuant to Article 1(a) of Council Directive 75/442/EEC on waste and Council Decision 94/904/EC establishing a list of hazardous waste pursuant to Article 1(4) of Council Directive 91/689/EEC on hazardous waste, OJ, L226, 3-24.

8. EC (2004) 2004/35/EC, Directive of the European Parliament and of the Council of 21 April 2004 on environmental liability with regard to the prevention and remedying of environmental damage, OJ, L143, 56-75.

9. EC (2008) $2008 / 1 / E C$, Directive of the European Parliament and of the Council of 15 January 2008 concerning integrated pollution prevention and control, OJ, L24, 8-29.

10. EC (2008) 2008/98/EC, Directive of the European Parliament and of the Council of 19 November 2008 on waste and repealing certain Directives, OJ, L312, 3-30.

11. EEA (European Environment Agency) (2002), Second technical workshop on contaminated sites, Workshop proceedings and follow-up, Technical Report No 76.

12. EEC (1991) 91/689/EEC, Council Directive of 12 December 1991 on hazardous waste (repealed), OJ, L377, $20-27$.

13. EU (2010) 2010/75/EU, Directive of the European Parliament and of the Council of 24 November 2010 on industrial emissions (integrated pollution prevention and control) (recast), OJ, L334, 17-119. 
14. EU (2011) 2011/92/EU, Directive of the European Parliament and of the Council of 13 December 2011 on the assessment of the effects of certain public and private projects on the environment, OJ, L26, 1-21.

15. EUROSTAT (2008), Methodologies and working papers, NACE Rev.2 Statistical classification of economic activities in the European Community.

16. Fetter C.W. (1999), Contaminant Hydrogeology, $2^{\text {nd }}$ Edition, Prentice Hall.

17. GWA DE (Government of Western Australia Department of Environment) (2004), Potentially Contaminating Activities, Industries and Land Uses (8/02/2005 V.3), Contaminated Sites Management Series, Available from http://www.dec.wa.gov.au/pollution-prevention/contaminatedsites/guidelines.html. (Accessed July 10, 2013).

18. Joint Ministerial Decision (2002) No 15393/2332/2002/GR harmonizing Greek environmental law with Directives 97/11/EC and 96/61/EC (repealed), Greek Official Gazette, FEK B, 1022, 1376513836.

19. JRC (Joint Research Center) (2011), Guidelines for EIONET data collection on contaminated sites 2006, as updated in 2011, http://eusoils.jrc.ec.europa.eu/library/data/eionet/2011_Contaminated_Sites.htm: Guidelines, (Accessed July 10, 2013).

20. Law (2011) No 4014/2011/GR, Law for environmental permitting for works and activities, Greek Official Gazette, FEK A, 209, 6215-6250.

21. MEECC (Ministry of Environment, Energy and Climate Change) (2010), Data from facility inspections of the HEI (Hellenic Environmental Inspectorate), available per request filed on April 23, 2010.

22. Ministerial Decision (2012) No 1958/13-1-2012/GR for the classification of public and private works according to law 4014/2012/GR, Greek Official Gazette, FEK B, 21, 213-276.

23. Ministerial Decision (2012) No 20741/8-5-2012/GR modifying Decision 1958/13-1-2012/GR, Greek Official Gazette, FEK B, 1565, 24161-24168.

24. Pantazidou M., Boura F., Pitsaki K. and Katsiri A. (2011), A methodology for compiling national inventories of contaminated sites: Key decisions and pilot applications in Greece, $12^{\text {th }}$ GNEST (Global Network for Environmental Science and Technology) Conference of Environmental Science and Technology, Rhodes island, Greece, Sept. 8-10.

25. Pitsaki K. (2010), Identification and assessment of potentially contaminated sites in Greece: An application for the paper and paint industries, Diploma Thesis, National Technical University of Athens, School of Civil Engineering, Department of Geotechnical Engineering.

26. Rodrigues S.M., Pereira M.E., Ferreira da Silva E., Hursthouse A.S. and Duarte A.C. (2009a), A review of regulatory decisions for environmental protection: Part I - Challenges in the implementation of national soil policies, Environment International, 35(1), 202-213.

27. Rodrigues S.M., Pereira M.E., Ferreira da Silva E., Hursthouse A.S. and Duarte A.C. (2009b), A review of regulatory decisions for environmental protection: Part II - The case-study of contaminated land management in Portugal, Environment International, 35(1), 214-225.

28. Royal Decree 9/2005 of 14 January 2005 which establishes a list of potentially soil contaminating activities and criteria and standards for declaring that sites are contaminated, Official Gazette of the Spanish State No. 15, 18 January 2005.

29. Tarazona J.V., Fernandez M.D. and Milagrosa Vega M. (2005), Regulation of contaminated soils in Spain, J. Soils \& Sediments, 5(2), 121-124.

30. USATSDR (US Agency for Toxic Substances and Disease Registry) (1997), Toxicological Profile for Trichloroethylene (TCE), Available from http://www.atsdr.cdc.gov/toxprofiles/tp19.pdf. (Accessed July 10, 2013).

31. USEPA (1989), EPA Superfund Record of Decision: Vogel Paint \& Wax Co. - OU 01 (Orange City, lowa), $\quad$ EPA/ROD/R07-89/027, Available from http://www.epa.gov/superfund/sites/rods/fulltext/r0789027.pdf. (Accessed July 10, 2013).

32. USEPA (1991), Guidance for Performing Preliminary Assessments Under CERCLA, EPA/540/G91/013, Publication 9345.0-01A, US Environmental Protection Agency Washington DC, Available from http://www.epa.gov/superfund/sites/npl/hrsres/pa/patoc.pdf. (Accessed July 9, 2013). 
33. USEPA (1992), EPA Superfund Record of Decision: Cosden Chemical Coatings Corp. - OU 01 (Beverly, New Jersey), EPA/ROD/R02-92/187, Available from http://www.epa.gov/superfund/sites/rods/fulltext/r0292187.pdf. (Accessed July 9, 2013).

34. USEPA (1998), EPA Superfund Record of Decision: Fletcher's Paint Works \& Storage - OU 01 (Milford, New Hampshire), EPA/ROD/R01-98/124, Available from http://www.epa.gov/superfund/sites/rods/fulltext/r0198124.pdf. (Accessed July 9, 2013).

35. USEPA (2002), Preliminary Assessment Petition, 9200.5-330FS, http://www.epa.gov/superfund/programs/npl_hrs/papetition_oct02.pdf. (Accessed July 9, 2013).

36. USEPA (2005), Guidelines for Carcinogen Risk Assessment, Risk Assessment Forum, EPA/630/P03/001B, US Environmental Protection Agency Washington DC, Available from http://www.epa.gov/ttn/atw/cancer_guidelines_final_3-25-05.pdf. (Accessed July 9, 2013).

37. USEPA (2013a), National Priorities List (NPL), Available from http://www.epa.gov/superfund/sites/npl/index.htm. (Accessed July 9, 2013).

38. USEPA (2013b), Sherwin-Williams/Hilliards Creek (Gibbsboro, New Jersey), Superfund Site Progress Profile - More in-depth site details (EPA Regional Content), Available from http://www.epa.gov/Region2/superfund/npl/0200516c.pdf. (Accessed July 10, 2013).

39. USEPA (2013c), Route 561 Dump Site (Gibbsboro, New Jersey), Superfund Site Progress Profile More in-depth site details (EPA Regional Content), Available from http://www.epa.gov/Region2/superfund/npl/0203909c.pdf. (Accessed July 10, 2013).

40. USEPA (US Environmental Protection Agency) (1986), EPA Superfund Record of Decision: Syncon Resins - OU 01 (South Kearny, New Jersey), EPA/ROD/R02-86/033, Available from http://www.epa.gov/superfund/sites/rods/fulltext/r0286033.pdf. (Accessed July 10, 2013).

41. USEPA IRIS (Integrated Risk Information System) (2013), Trichloroethylene Carcinogenicity Assessment for Lifetime Exposure, Available from http://www.epa.gov/iris/subst/0199.htm. (Accessed July 10, 2013).

42. Van-Camp L., Bujarrabal B., Gentile A.R., Jones R.J.A., Montanarella L., Olazabal C. and Selvaradjou S.K. (2004), Reports of technical working groups established under the thematic strategy for soil protection, Vol. 4, Contamination \& Land Management, EUR 21319 EN/4. 